\title{
3. つくば高血圧マウスとつくば低血圧マウス
}

\author{
村上 和 雄 深 水 昭 吉 \\ 筑波大学 応用生物化学系

\section{Tsukuba Hypertensive and Tsukuba Hypotensive Mice}

Kazuo MURAKAMI and Akiyoshi FUKAMIZU

Institute of Applied Biochemistry, University of Tsukuba

\begin{abstract}
Summary
We first constructed the chimeric renin-angiotensin cascade in mice comprising both human renin (h-RN) and human angiotensinogen (h-ANG) as well as the endogenous angiotensin converting enzyme and angiotensin II receptors. Although each single gene carrier did not develop hypertension, dual gene strains with the overactive RAS (Tsukuba hypertensive mice) exhibited a chronically sustained increase in blood pressure. During the crossmating experiments, we observed that transgenic female mice carrying the h-ANG gene, which displayed normal blood pressure in the nonpregnant state, developed hypertension at 19 days of gestation, only when they had been mated with transgenic males carrying h-RN. Pregnant females derived from other mating combinations did not show hypertension. On the basis of these results, we hypothesized that combination of paternal renin and maternal angiotensionogen meght play a role in the development of pregnance-associated hypertension.

We next generated angiotensinogen- and angiotensin type 1a receptor (AT1a)-deficient $(-/-)$ mice. The systolic blood pressure of angiotensinogen- and ATla-deficient mice dropped 33.5 and $22 \mathrm{mmHg}$, respectively, in comparison with that of the wild-type $(+/+)$ mice. Angiotensinogen-deficient mice $(-/-)$ was called Tsukuba hypotensive mice.

These observations demonstrated an indispensable role for the RAS in the blood pressure regulation.
\end{abstract}

\section{緒 言}

レニン・アンギオテンシン (RA) 系は, 血圧調節 を含む心血管系の恒常性や高血圧症などの発症に重要 な役割を演じていると考えられている.

1980 年代の前半から, レニン・アンギオテンシン系 の研究に遺伝子工学的手法が導入され，RA 系の主要 な成分である，レニン，レニン基質（アンギオテンシ ノーゲン)，アンギオテンシン II 変換酵素の cDNA や核内遺伝子のクローニングが成功した。 その結果, これらの遺伝子の構造や，その遺伝子の調節に関与す る部位が次々と明らかになった。そして, これら遺伝 子の細胞内での調節機構に関する研究もさかんになっ ていった.これらの結果を基盤として, 1980 年代の 後半から RA 系の発生工学的研究が開始された.

\section{実験方法および成績}

I . 遺伝子導入マウス

1）ヒト・レニンとヒト・アンギオテンシノーゲンの 両遺伝子を有するマウス（つくば高血圧マウ ス) ${ }^{11}$

(1) まず，調節部位を含むヒト・レニン遺伝子を持っ た遺伝子導入（トランスジェニック）マウスを作製し た. ヒト・レニンはこのマウス腎の傍系球体細胞で主 として発現したが，血圧は正常であった。ついで，(2) ヒト・アンギオテンシノーゲン（ヒト・Agt）を有する 遺伝子導入マウスを作製したが，その血圧も正常であ った. そこで，(1) と（2)の交配により，ヒト・レニン とヒト・Agt 遺伝子を持ったマウスを作製した。この マウスは, 正常マウスより 30〜 $40 \mathrm{mmHg}$ 高い血圧を 有し, この血圧は, ヒト・レニンの特異的阻害剤の投 与により正常血圧にもどった。このマウスを「つくば 
Table 1 Systolic blood pressure of Tsukuba hypertensive and hypotensive mice

\begin{tabular}{lc}
\hline & $\begin{array}{c}\text { Systolic blood } \\
\text { pressure }\end{array}$ \\
\hline Tsukuba hypertensive mice & $129.1 \pm 7.1$ \\
Wild type mice & $100.4 \pm 4.4$ \\
Tsukuba hypotensive mice & $66.9 \pm 4.1$ \\
\hline
\end{tabular}

高血圧マウス」と命名した（Table 1).

このマウスにおける血漿中にヒト・レニンおよびヒ ト・Agt が存在することが明らかとなった。ささらに, ヒト・レニンとヒト・Agt 間の反応がマウスの血中で 起こっているかについては, 野生型マウスと比較し, 両遺伝子保有マウスでは血漿アンギオテンシン I （AI）量が 3〜4 倍上昇していることから，ヒトの䤉 素と基質の反応がマウス個体において起こっているこ とが実証された。

また, 両遺后子保有マウスにおける AI の上昇は, 同様にアンギオテンシンII（AII）の上昇を導き， RA 系の最終活性ペプチド（AII）が循環中に過鄱に 生成されていることが明らかとなった。

つくば高血圧マウスの血圧は，ヒト・レニンを特異 的に抑制する薬㓣の投与により顕著に低下したが，野 生型マウスや, ヒトの一つの遺伝子のみを導入したマ ウスにおいては, 血圧の低下が認められなかった。こ れらの結果より, つくば高血圧マウスにおいては, ヒ ト・レニンとヒト・Agt の特異的反応により産生した 過剩な $\mathrm{AI}$ が, 内在性のマウス・アンギオテンシン変 換酵素により AII に変換され, 高血圧を引き起こし ていることが明らかとなった。

\section{$\diamond$ 病態解析}

RA 系は，高血圧の成因のみならず心肥大や動脈硬 化においても中心的役割を担っている可能性が報告さ れている。私どもが開発したつくば高血圧マウスにお いても次のような興味深い病態が出現していた．多く の個体において 3 力月齢までに心肥大が起こり, 加齢 とともに顕著な心肥大が観察された.さらに, 心筋細 胞の肥厚へと病態が進行する個体もかなりの頻度で出 現する。また，大動脈茎部より大動脈弓部における血 管破裂を起こす個体も出現する。 さらに，6力月以降 において, 堅系球体硬化病変が高頻度に出現する.

また最近, つくば高血圧マウスに高脂肪, 高コレス
テロール食を捸取させると, 䋆状動脈硬化の進展が顕 著に六進することが明らかとなった ${ }^{2)}$.

したがって，つくば高血圧マウスは，単に，高血圧 の病態を解析するのみでなく, RA 系と心肥大, 動脈 硬化および腎障害などの組織病変の関係を解析する非 常に有用なモデルである。

2）妊娠高血圧マウス ${ }^{3)}$

ごく最近になり, 上述したつくば高血圧マウスの作 製過程において，ヒト・レニン遺伝子を導入したオス マウスとヒト・Agt 遺伝子を導入したメスマウスを交 配させると, メスマウスの血圧が妊娠後期に上昇し, 妊娠末期においては, 大動脈弓部の血管破裂により, また心不全により半数以上が死亡するという非常に興 味深い現象を見いだした。そこで私どもは, 今回観察 された現象が胎児由来の胎盤レニンにより引き起こさ れたものと予測を立て, 胎盤レニンの母体透過性およ び母体血圧への影響を発生工学的手法から解析した。 まず初めに，野生型（C57BL/6J) のメスマウスに ヒト・レニン遺伝子を導入したオスマウスを交配させ る実験系を組み立てた，もし，胎盤で発現するレニン が母体に透過性をもつならば，ヒト・レニン遺伝子を もたない野生型メスマウスの血中にヒト・レニンが検 出されると考えられた. 出産前日の妊娠 19 日目の胎 盤では，大量のヒト・レニン mRNA が検出され，そ の発現量はつくば高血圧マウスのメスの腎臓の約 8 倍 を示した。 また, 胎盤の組織抽出液中のヒト・レニン 量を, ヒト・レニン特異的抗体を用いて解析したとこ ろ, 大量の活性型および不活性型ヒト・レニンが検出 され, 野生型メスマウスの胎盤において，ヒト・レニ ンが mRNA およびタンパクレベルで大量に発現して いることが示された。

次に私どもは, 野生型メスマウスの血㢡中のヒト・ レニン量の測定をおこなった. その結果, 妊娠 19 日 目の母体血漿中には，正常なヒト血槳にくらべ大量の 活性型ヒト・レニンが, また, その約 34 倍の不活性型 ヒト・レニンが存在するが明らかとなった。この結果 は, 胎盤レニンが母体循環液中に放出される決定的な 証拠であり, 今回観察された現象については, 次のよ うな発症機序が考えられた。

ヒト・レニン遺伝子を導入したオスマウスと交配す ることにより,メスマウスの胎盤ではヒト・レニンが 大量に発現する.また，このヒト・レニンは母体に透 過性をもつため母体血中に大量に放出される, 一方, 
母体はヒト・レニン基質であるヒト・Agt 遺伝子をも つため, 母体内ではヒト・レニンとヒト・Agtにより 種特異的な RA 反応が生じ， AI および AII の過剩生 成が起こり，血圧が上昇したと考えられた。またこれ らが引き金になり，大動脈弓部の血管破裂および心不 全が発症したと考えられる。

実際に，妊娠 19 日目における収縮期血圧は，野性 型マウス同士を交配させたコントロールでは, 非妊娠 と同様, 正常血圧 $100 \mathrm{mmHg}$ 程度を示したのに対し, ヒト・レニン遺伝子をもつオスマウスと交配したヒ ト・Agt 遺伝子をもつメスマウスでは $156 \mathrm{mmHg}$ と非 常に高い血圧を示した。また，このとき母体血漿 AII 量はコントロールに比べ, 約 6 倍と顕著に増加してい た.

\section{II. 遺伝子欠損マウス}

1）つくば低血圧マウス（アンギオテンシノーゲン (Agt） 欠損マウス $)^{4)}$

私どもはまず， RA 系唯一の基質である Agt の破 壊を行った。その結果, 野生型マウスおよびへテロ変 異型マウスにおいては, Agt 遺伝子発現が検出された が，ホモ変異型マウスにおいては，同遺伝子の発現は 検出されなかった。このことにより個体レベルにおい て, Agt 遺伝子の半分または完全な欠損に成功したこ とが示された.さらに，これらマウス血獎中の Agt および $\mathrm{AI}$ の産生は, . ホモ変異マウスにおいては検出 限界以下であり, 本動物が Agt 欠損マウスであり, RA 系が機能しないマウスであることが明らかとなっ た.そこで，このマウスの血圧を悲観血式に測定した ところ, 野生型マウスとへテロ変異型マウスとの間に は血圧に有意な差が観察されなかったのに対し，この ホモ変異型マウスでは血圧が, 野生型マウスと比較す ると, 収縮期血圧で $34 \mathrm{mmHg}$ も低く，このマウスを 「つくば低血圧マウス」（Table 1）と命名した。これ らのことは，血圧維持において RA 系を代償する昇 圧系は存在せず, 正常血圧制御においてもRA系が 重要な役割を演じていることが明確に示された。現 在, このつくば低血圧マウスの病態の解析中である.

2) アンギオテンシン II 受容体遺伝子久損マウス ${ }^{5)}$

アンギオテンシン II（AII）受容体は，少なくとも 二つの型（1 型と 2 型）があり, 1 型には $1 \mathrm{a} と 1 \mathrm{~b}$ 型がある. 従来知られていた AII の作用は, そのほ とんどが 1 型を介して伝達されると推定されている. この推定を実証し,さらに $1 \mathrm{a}$ および $1 \mathrm{~b}$ 型の役割を
明らかにするため, 多くの藏器で発現している $1 \mathrm{a}$ 型 の遺伝子が欠損しているマウスを，私どもは 1995 年 に創作した，このマウスの最高血圧は，コントロー ル・マウスに比べ, ヘテロ型では $10 \mathrm{mmHg}$, ホモ型 では $22 \mathrm{mmHg}$ それぞれ低下していた。この結果は， $\mathrm{RA}$ 系による血圧のコントロールには, $1 \mathrm{a}$ 型受容体 が重要な役割を演じていることを示している.

ごく最近, 稲上らは 2 型受容体の生理的意義を解明 するため，この受容体遺伝子を欠損したマウスを作製 することに成功した ${ }^{6)}$. 2 型受容体は, 胎児の皮膚に 多く発現していることから，胎児発育などに重要な作 用をもつ受容体であると考えられていた。しかし，予 想に反し， 2 型受容体を欠損したマウスは，その血圧 が顕著に上昇しており (25〜30 mmHg), さらに, 静 脈に注入した AII に対して過敏な血圧上昇作用を示 すことがわかった。

したがって,この 2 型 AII 受容体は, 主として, 血圧上昇を抑える作用をもつことがわかった，AII は 血圧の調節に関して, 全く相反する作用を有すること が明らかとなった。すなわち, AII は 1 型受容体 （AT1）を経由して血圧を上昇させる一方，2 型受容 体（AT2）を経由して血圧を降下させるという，大 変興味ある事実が判明した。この事実は，AII が血圧 上昇という生理作用に関して,アクセル（1 型受容 体）とブレーキ（2 型受容体）を巧みに使い分けてい ることを示している.

\section{総 括}

レニン・アンギオテンシン（RA）系の研究は, 次々と新しい技術を導入することによって進歩してき た.これらの技術により $\mathrm{RA}$ 系の各成分の基本構造 はもとより, RA 系の遺伝子導入マウスや遺伝子久損 マウスの創作まで, 研究がほほ完成した。ここまで研 究が進むとは, 研究を始めたときには全く予想できな かった。これらの技術により, 分子レベルから個体レ ベルまでの RA 系の研究は一つのゴールを迎えたこ とになる.

しかし, これらの研究の一つの到着点である遺伝子 導入マウスや遺伝子欠損マウスの創作は, 新しい研究 の出発点でもある.これらの新しいモデル動物を使っ て, RA 系の血圧調節以外の新しい生理作用, 特に組 織における RA 系の役割の解明を期待している. 


\section{文献}

1) Fukamizu, A., Sugimura, K., Takimoto, E., et al.: J. Biol. Chem., 268, 11617 (1993)

2) Sugiyama, F., Haraoka, S., Watanabe, T., et al.: Lab Invest, 76, 835 (1997)

3) Takimoto, E., Ishida, J., Sugiyama, F., et al.: Science, 274, 995 (1996)
4) Tanimoto, E., Sugiyama, F., Goto, Y., et al.: J. Biol. Chem., Commun., 269, 31334 (1994)

5) Sugaya, T., Nishimatsu, S., Tanimoto, K., et al.: J. Biol. Chem., 270, 18719 (1995)

6) Ichiki, T., Labosky, P.A., Shiota, C., et al.: Nature, 377, 748 (1995) 